\title{
Stand evaluation, crop estimation and yield analysis of winter wheat for the optimization of yields
}

\author{
Nárcisz Pap - János Pap - Rezső Schmidt \\ SZE - MÉK Mosonmagyaróvár Vár - tér 2 \\ narcisz.pap@gmail.com
}

SUMMARY

\begin{abstract}
The authors have been carrying out stand evaluation, crop estimation and yield analysis in winter wheat since 2012. The sampling areas were assigned at the fields of the Training Farm of the Faculty of Agricultural and Food Sciences of Széchenyi István University Mosonmagyaróvár according to the structure of the cropping system. According to their observations the value of field emergence is always lower than the laboratory germination. The weak emergence is important because the lower plant density cannot be compensated by the increased tillering in spite of having larger plant growth space. It is proven by the fact that they detected strong productive tillering even at 5 and 10 mm plant spacing while there were single-spiked plants at 40-50 mm plant spacing as well. The analysis revealed that the total ear mass and grain mass of wheat plants bearing two or more ears is almost the double than that of the single-spiked plants. It was a further basic experience that the largest ear of "multiple-spiked" plants is always heavier than the single ear of one-spiked plants. Plants with intense tillering and more ears demonstrate the importance of proper seedbed preparation and drilling and the significance of sowing good quality seeds. These are the factors that determine field germination and emergence, influence the speed and intensity of initial development and by all these factors the sufficient productive tillering. The authors emphasize the use of exact and objective methods at crop estimation, e.g. the relationship between the ear mass and the yield which is in strong correlation whilst ear length and grain mass are not suitable for a precise estimation. The authors conclude that crop estimation and yield analysis must be inevitable tools of modern crop production and will be particularly important in precision agriculture. These tools also qualify the job done by farmers and helps to identify the areas that require special attention.
\end{abstract}

Keywords: field germination, productive tillering, plant growth space, ear length, ear mass

\section{INTRODUCTION AND LITERATURE REVIEW}

World population is projected to reach over nine billion by 2050 , and ensuring food security while mitigating environmental impacts represents a major agricultural challenge. Thus, higher productivity must be reached through sustainable production by taking into account climate change, resources rarefaction like phosphorus and water, and losses of fertile lands. Enhancing crop diversity is increasingly recognized as a crucial lever for sustainable agro-ecological development (Bedoussac et al., 2015).

The climate variability impact on wheat production concerning mitigation strategies is need of time in order to reduce the risk of climate change on crop yield and growth (Ali et al., 2017).

Agronomic practices such as cultivar choice, water and nitrogen supply, nutrients availability and growing conditions should be taken into account to design adaptation options (Ali et al., 2017).

Stand evaluation, crop estimation and yield analysis are important tools in plant production (Pap, 2007). The importance of stand evaluation and obtaining preliminary information about the predictable yield is emphasized by a decree of the Hungarian Ministry of Agriculture (FVM 109/2007. (IX.28). Knowing the expected yield already before harvest is important and necessary (Simon, 1985). The reliability of subjective crop estimation depends largely on the practice and experience of the person who does it and also on the ecological factors of the area.

Cereal breeders have used harvest index (HI) as a selection criterion in segregating generations to identify physiologically superior lines with improved partitioning of total assimilate into grain (Sharma et al., 1991).

Yield is influenced more so-called vegetation elements that can be monitored during the vegetation period (Simon, 1974). The vegetation elements are influenced by the variety, the location, crop year, the drilling technology, therefore these elements have to be monitored and registered every year. Temperature variability proved to be an important factor and influenced both mean and standard deviation of the yields (Trnka et al., 2004).

Depending on these elements the yield shows great variation (Pap et al., 2009c.). The important and decisive role of field germination and emergence is emphasized by Pap et al., 2011. The value of field germination can be monitored during the process of stand evaluation and crop estimation (Pap et al., 2009a). Pap et al. (2018) established that tillering cannot compensate the yield of the missing plants therefore we have to strive to achieve the possible smallest difference between germination and field emergence.

They also observed that tillering can be strong in high plant density stands too and on the contrary it is not sure that in lower density stands plants will produce better tillering. Within crop estimation procedures we differentiate between subjective and objective methods. Subjective methods can be divided into stand evaluation and numerical estimation (Simon, 1974). Regarding the accuracy of crop estimation the following methods can be specified: subjective or visual estimation, objective evaluation based on yield components and yield mass and finally the inclusion of the analysis of major factors influencing yield, e.g. weather conditions (Nátr, 1985). At winter wheat the 
first step is the autumn stand evaluation - end of November, beginning of December. At this time we can evaluate the field emergence, plant density, vegetative development of plants, sowing depth, tillering, stub length, plant height. The time of the first spring evaluation is the beginning or the middle of April, the time of the second evaluation is the beginning or the middle of May. The predicted yield is calculated according to a formula based on the values of plant density, ear number per unit area, number of grains in the ears and thousand-kernel weight (Láng, 1970). The objective crop estimation of wheat is done before harvest when the ears in the sample area are counted and the length of the first ten ears are measured. Then the expectable yield per hectare is determined by a table of assessment (Kováts and Ragasits, 1981). A week correlation was detected between the length of the ears and yield, but the correlation between ear mass and yield was strong (Pap et al., 2010). At common spring barley the expected yield is calculated from the number of ears per unit area, the average grain number in the ears and from the empirical thousand-kernel weight
(Kismányoky, 1981). The correctness of crop estimation is provided by the sufficient degree of representation when the data of the sampling areas are in good correlation with the whole field (Pásztor, 1981). For a correct crop estimation, it is necessary to gather all the available and measurable data since numerous factors, e.g. the particular crop year, the location of the field or even the applied production technology can modify significantly the average values in the tables of assessment (Pap et al., 2009b).

\section{RESULTS}

The sowing of wheat took place between the $3^{\text {rd }}$ and $23^{\text {rd }}$ of October in the experimental years. The first autumn field evaluation was carried out between the $9^{\text {th }}$ and $26^{\text {th }}$ of November depending on the sowing time (Table 1).

The number of seeds sown were 4.6 million in the first two experimental years and 5.8 million in 2014 respectively.

The basic data of stand evaluation and yield estimation - based on the average of the sampling areas - in the years of 2012 and 2014

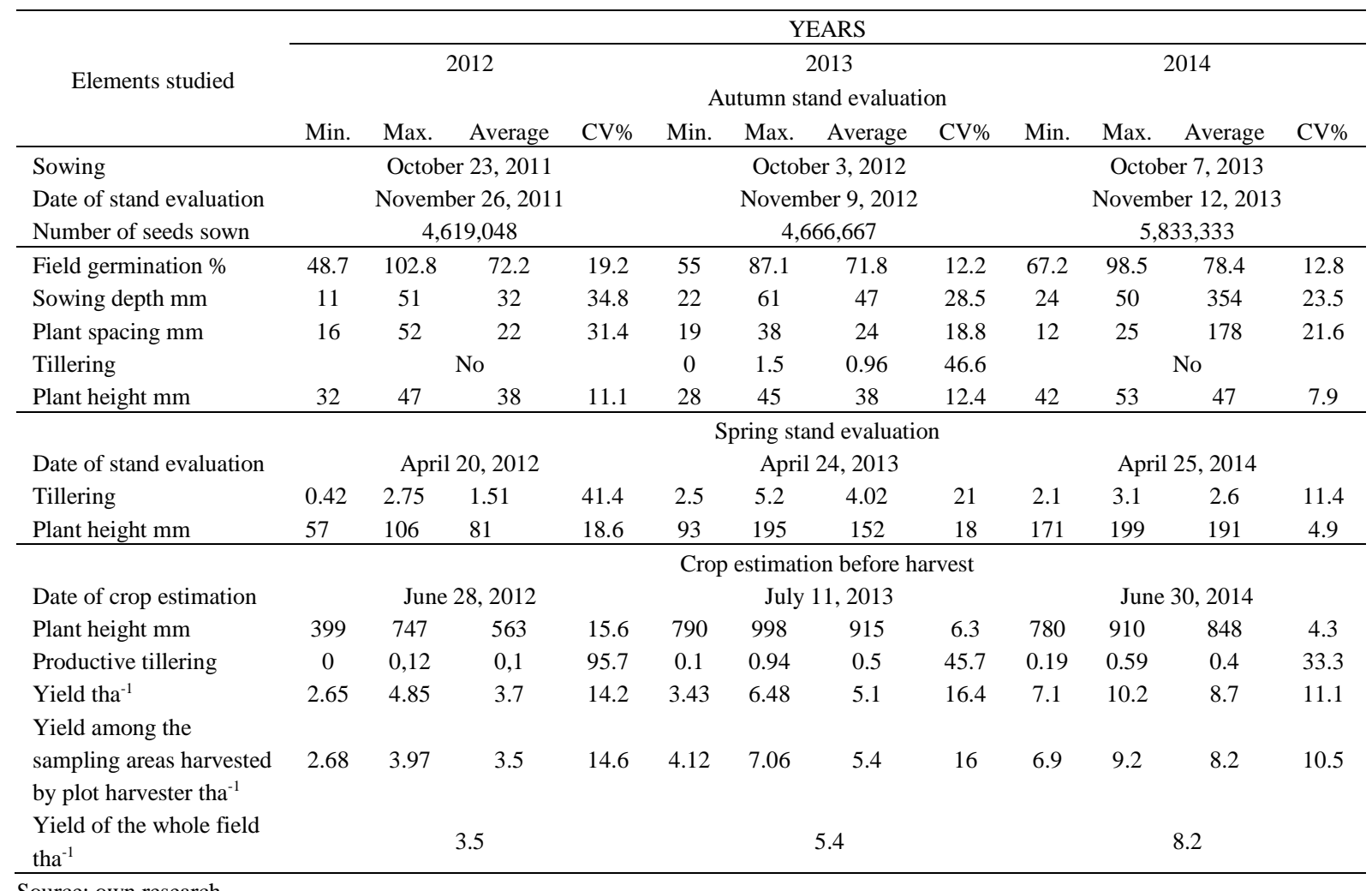

Source: own research

The most important task at autumn field evaluation is to establish field germination. This value cannot be found in the literature and personal experience doesn't help either. The only possibility is to make random sampling on the particular field. Field germination supplies information about two important facts at the same time. It displays if the farmer had everything possible done, including seedbed preparation, time and way of sowing, etc. in order to achieve the closest correlation between laboratory and field germination. In other words, field germination is a qualification value of sowing. On the other hand - and it is often ignored by farmers - field germination supplies information (in case the previously mentioned technological elements were carried out correctly) about the quality and origin of seeds and about the facts 
if storage and other postharvest technological steps were done correctly. Mistakes in these factors also may result in poorer field germination. A key aspect of plant production is that field germination and plant density is an extremely important factor in determining the amount and quality of yield, therefore every effort has to be made for achieving high field germination.

Regarding field germination, we can establish that in all three years it significantly fell behind the laboratory germination values (Table 1). Based on the averages of the sampling areas it varied between 72 and 78 percent, but what is more important the standard deviation was above the acceptable level ranging

Figure 1: Sowing depth

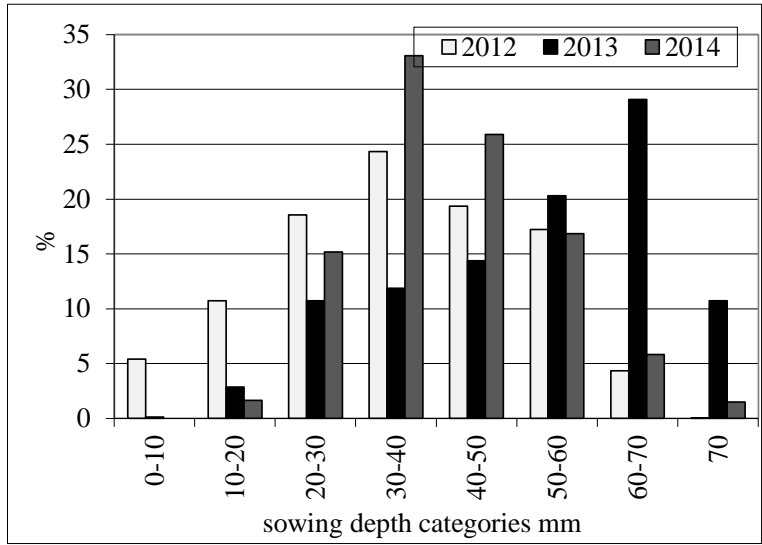

Measuring all plants on the sampling areas we can establish that on the one hand sowing depth lower than $30 \mathrm{~mm}$ is very frequent, which may increase frost damage - winter kill - and on the other hand the occurrence of sowing depth higher than $60 \mathrm{~mm}$ is also common, which can result in slower emergence when plants reach the surface of the soil in weak condition and are more susceptible to pests and pathogens. The uneven sowing depth and poor seedbed quality together may be responsible to a great extent for the insufficient field germination (Table 1, Figure 1).

Figure 2 displays that plant density in the case of almost 40 percent of the plants is higher than the ideal value (taking 5 million seeds and $120 \mathrm{~mm}$ row distance as a standard this value is about $17 \mathrm{~mm}$ ). The occurrence of plant spacing higher than the ideal is also almost 30 percent. These values prove that sowing uniformity is not sufficient. In the sampling areas the average plant spacing is higher than the optimum and there is a high variation among the sampling plots (Table 1).

In the years 2012 and 2014 we didn't find plants in the tillering phase though in 2013 we found 1 side shoot per plant on the average (Table 1).

The development of plants is well indicated by their height (Table 1, Figure 3). The data display that though between 12 and 19 percent. As a result of the uneven germination the number of samples had to be increased for a more precise estimation.

One of the reasons of the uneven germination could be the high variation in sowing depth. The extreme values in the particular experimental years were 10 and $60 \mathrm{~mm}$ respectively though the average was between 30 and $50 \mathrm{~mm}$. The variation of sowing depth among the sampling areas was twice as high as the variation of the field germination. It draws the attention to the fact that the accuracy of sowing was very low whilst the exact sowing and the proper sowing depth is an inevitable precondition of uniform plant development.

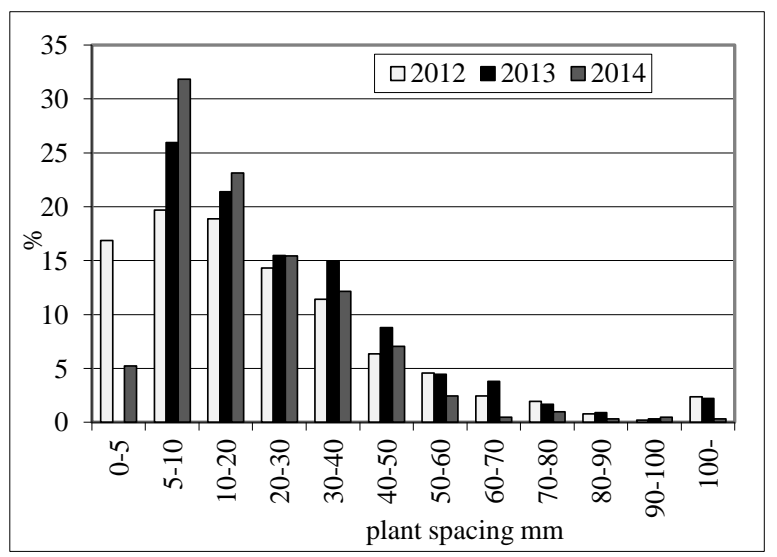

with a considerable variation but the plants went into the winter underdeveloped which was the result of the slow and heterogeneous emergence and one of its reasons was definitely the uneven sowing depth.

During the spring survey - between 20 and 25 of April - already better tillering was registered than on the occasion of the autumn stand evaluation (Table 1 , Figure 4). In 20121.5 side shoots were recorded in the average of the sampling areas. In 2013 there were 4 shoots which is quite favourable and in 20142.6 side shoots were detected per plant. At the same time unfortunately there was a high variation among and within the sample areas as well (Figure 4).

The development of plants is well indicated by Figure 5 which displays that with a high variation but the plant height values in 2012 are only the half of that of in 2014. The height values in 2013 are between the figures of the previously mentioned two years. The special importance of this pattern will be revealed when we compare it to yield values measured in each particular year. The data in Table 1, and Figure 7 show that yield values follow a similar tendency. It means that the development and condition of the plant stands (e.g. tillering) even at spring already provide a good forecast regarding the yield in that particular year with the given technology. 
Figure 3: Plant height

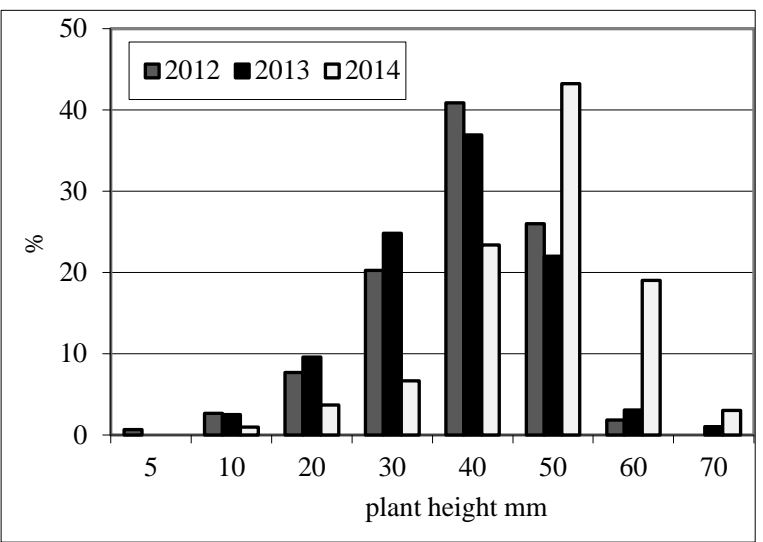

Figure 5: Plant height at spring

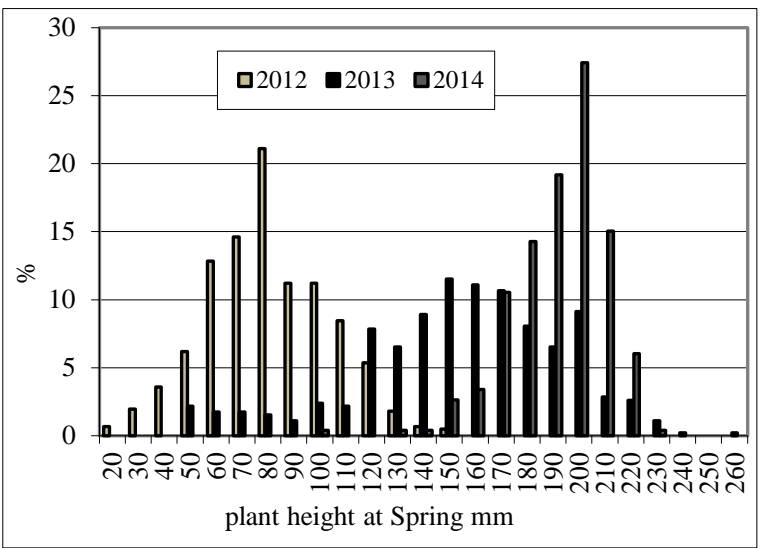

The crop estimation in the years studied was carried out between June 28 and July 11 . Besides the measurement of the yield we determined and publish in this paper the height of the wheat plants and the productive tillering (Table 1, Figure 6). In 2012 the wheat plants were relatively short and the height varied between 400 and $750 \mathrm{~mm}$ with an average of $563 \mathrm{~mm}$, but there was a high variation among the sampling areas. In the years of 2013 and 2014 the plants were more uniform, the height values varied between 915 and $848 \mathrm{~mm}$ and the variation among the sampling areas is within the acceptable range.

In 2012 there was hardly any productive tillering, we could find a second ear only on every tenth plant and there was a high variation among the sampling areas. The situation is better in the next two years when almost every second plant bears a second ear though the variation among the sampling areas was high in these years too (Table 1).

In the average of the sampling areas the yield and the other parameters measured follow similar tendency (Table 1, Figure 7). The yield in 2014 is more than the double compared to that of in 2012 whilst the yield measured in 2013 falls between the two a little closer to
Figure 4: Number of side shoots

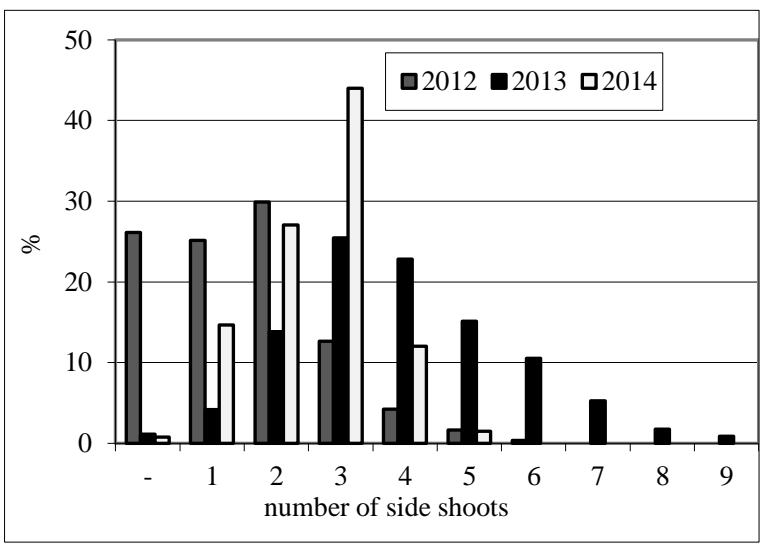

Figure 6: Plant height at harvest

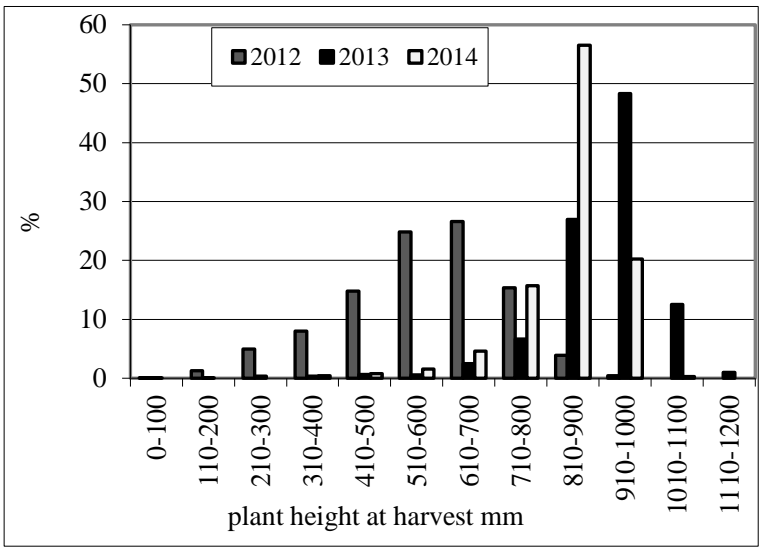

the 2012 figures. For the validation of our crop estimation we harvested the plants among the sampling areas with a plot harvester and we got the same result. This accuracy can be attributed to the sufficient sample number, the proper random assignment of the sampling areas and to the satisfactory precision of the measurements. A similar tendency can be established regarding the yield of the sampling areas and that of the whole field.

During the crop estimation we paid special attention to the evaluation of plants with tillering and plants without side-shoots and compared their yield potential (Table 2, Figure 8). Our experience was that the largest ear of plants with productive tillering was always heavier than the single ear of plants without sideshoots. It is worth mentioning that we could not find any data describing this phenomenon in the Hungarian and international literature. Evaluating these data, the relationship proved to be significant. On the contrary farmers generally think that the spikes of single-stem plants are heavier therefore they generally increase the number of seeds sown paying no attention to tillering. 
Figure 7: Yield of wheat per plant

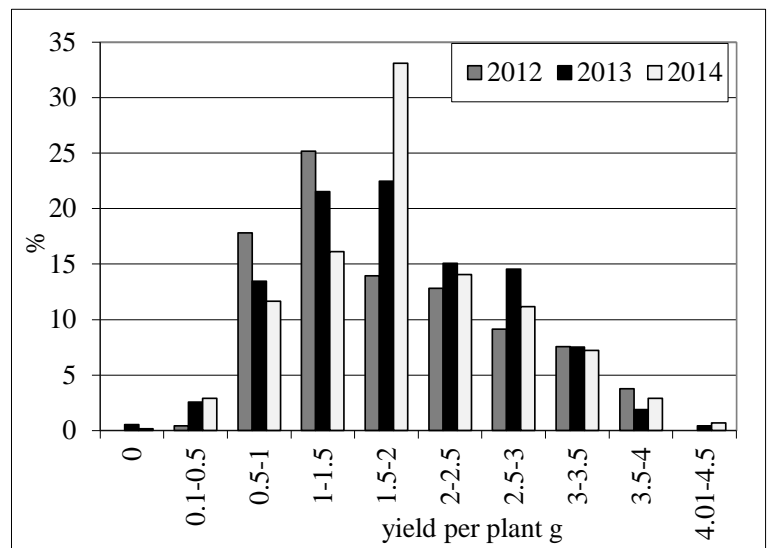

Figure 8: The relationship between earmass and tillering

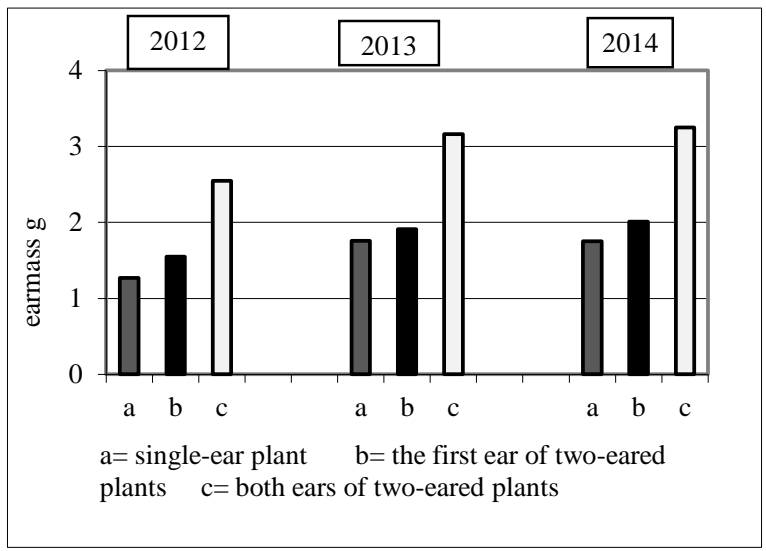

Mass of grain per wheat plant and the plant growth space

\begin{tabular}{|c|c|c|c|c|c|c|}
\hline \multicolumn{7}{|c|}{ Years } \\
\hline & \multicolumn{2}{|c|}{2012} & \multicolumn{2}{|c|}{2013} & \multicolumn{2}{|c|}{2014} \\
\hline \multicolumn{7}{|c|}{ Ear mass and its distribution } \\
\hline & $\mathrm{g}$ & $\%$ & g & $\%$ & g & $\%$ \\
\hline a & 1.27 & 100 & 1.76 & 100 & 1.75 & 100 \\
\hline $\mathrm{b}$ & 1.55 & 123.1 & 1.91 & 111.4 & 2.01 & 114.9 \\
\hline $\mathrm{c}$ & 2.55 & 200 & 3.16 & 179.5 & 3.25 & 185.7 \\
\hline \multirow{2}{*}{\multicolumn{7}{|c|}{ ar (single-eared plants) }} \\
\hline & & & & & & \\
\hline \multirow{2}{*}{\multicolumn{7}{|c|}{$\begin{array}{l}\mathrm{b}=\text { mass of one ear (more-eared plants) } \\
\mathrm{c}=\text { total ear mass of more-eared plants }\end{array}$}} \\
\hline & & & & & & \\
\hline \multicolumn{7}{|c|}{ Years } \\
\hline & \multicolumn{2}{|c|}{2012} & \multicolumn{2}{|c|}{2013} & \multicolumn{2}{|c|}{2014} \\
\hline \multicolumn{7}{|c|}{ plant growth space } \\
\hline & $\mathrm{cm}^{2}$ & $\%$ & $\mathrm{~cm}^{2}$ & $\%$ & $\mathrm{~cm}^{2}$ & $\%$ \\
\hline A & 23.5 & 100 & 32.52 & 100 & 20.34 & 100 \\
\hline B & 24.2 & 103 & 34.83 & 107 & 22.9 & 112.6 \\
\hline SzD5\% $\mathrm{LSD}_{5} \%$ & - & & - & & - & \\
\hline \multicolumn{7}{|c|}{$\mathrm{A}=$ =plant growth space (single-eared plants) } \\
\hline \multicolumn{7}{|c|}{$\mathrm{B}=$ plant growth space (more-eared plants) } \\
\hline
\end{tabular}

Source: own research

According to our experience we think that is had several reasons. The first one is that the root system of plants with better tillering is larger and more developed therefore it can absorb more water and nutrients from the soil. The second one is that plants transport the nutrients primarily to the main ear hence it will be larger and heavier. Moreover, it is obvious that the yield of plants with productive tillering will be much higher - even 2-3 times higher - than that of the plants with one single ear only. The positive effect of tillering can be experienced very well in the years of 2013 and 2014 which explains the higher yields in spite of the different variety, technology and conditions in the particular years.

The effect and significance of productive tillering is highlighted by the fact that there is only a $5-10 \%$ difference in the growing area of the plants with tillering and that of the plants with one single ear only (Table 2). The relationship between the breeding area and the yield draws the attention to the fact that lower seeding rate cannot be compensated by tillering. Tillering is not a matter of breeding area; it rather depends on sowing, the time, quality and method of it. We have to make every effort for good field germination and emergence and for strong tillering including good seedbed preparation, the using of good quality seeds and good drilling technology.

After harvest we carried out a yield analysis and studied the role of individual yield components, - such as plant height, plant density, number of ears on a unit area, number of grains per ear and thousand-kernel weight - in the formation of the final yield. Using these five components we created a so-called "yield 
component indicator" and compared it to the real yield (Figure 9).

Figure 9: The relationship between the yield components and the yield

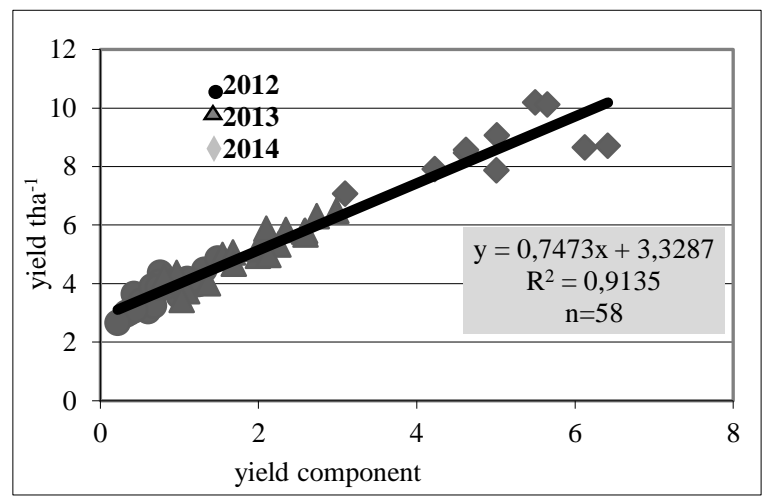

In the average of the sampling areas the indicator obviously shows the variation within the data of the given year and the difference in the 5 yield components comparing the particular year to another one, e.g. 2014.

When the results of two years are overlapping each other, - e.g. 2012 and 2013 - the data indicate clearly that the difference among the sampling areas exceeds the difference among the years. It means that on a particular part of the area the lower yield cannot be attributed to the effect of the year it has some other reason. The yield component indicator reveals that in favourable situations the plant density is high, and so is the ear number which is determined by tillering besides the seeding rate and emergence. The high number of grains in he ears and high grain density is also desirable.
Some of these factors are determined by crop year effects, but others, such as plant density, ear number, number of grains in the ears, thousand-kernel weight can be influenced by the farmer and can be optimized by applying proper technologies.

\section{CONCLUSIONS}

The low - less than $80 \%$ - field germination values are caused by improper seedbed preparation and bad quality drilling.

There was no significant relationship between tillering and plant growth space. It supports the assumption that productive tillering will not compensate lower plant density. At smaller plant growth space we will also find plants with strong tillering and there were single-spiked plants on large growth areas as well.

Weak emergence wasn't always followed by strong tillering. In 2013 and 2014 the productive tillering that resulted 1.4-1.5 ear per plant compensated the weak emergence only to a minimum extent.

There was a marked relationship between tillering and the mass of ears on plants with good tillering. According to our observations the largest ear of plants with good tillering is heavier than the only ear of singlespiked plants. Furthermore, the total ear mass of plants with good tillering can be two times higher than that of single-spiked plants.

This latter relationship underlines the importance of proper and good quality seedbed preparation and drilling in order to achieve the possible best field germination and emergence.

\section{REFERENCES}

\section{9/2007.(IX. 28.) FVM rendelet}

Ali, S. A.-Tedone, L.-De Mastro, G. (2017): Climate Variability Impact on Wheat Production in Europe: Adaptation and Mitigation Strategies. In: Ahmed M., Stockle C. (eds) Quantification of Climate Variability, Adaptation and Mitigation for Agricultural Sustainability. Springer, Cham https://doi.org/10.1007/978-3-319-32059-5_12

Bedoussac, L.- Journet, E.P - Hauggaard-Nielsen, H. - Naudin, C. Corre-Hellou, G. - Steen Jensen, E. - Prieur, L. - Justes, E.(2015): Ecological principles underlying the increase of productivity achieved by cereal-grain legume intercrops in organic farming. https://doi.org/10.1007/s13593-014-0277-7

Kismányoky, T. (1981): Sörárpa. In Kováts, A Növénytermesztési praktikum. Mezőgazdasági kiadó. Budapest.

Kováts, A.-Ragasits, I. (1981): Búza. In Kováts, A Növénytermesztési praktikum. Mezőgazdasági kiadó. Budapest.

Láng, G. (1970): A búza. A növénytermesztés kézikönyve. Mezőgazdasági Kiadó. Budapest.

Nátr, L. (1985): A növénytermesztés elméleti és gyakorlati fejlesztésének új irányai. In. Jiri, P. - Vladimir, C. - Ladislav, H. (szerk) A föbb szántóföldi növények termésképződése. Mezőgazdasági kiadó. Budapest.
Pap, J -Pap, V.-Pap, N.-Tuller, P. (2009a.): A szántóföldi kelés jelentősége. Mezőgazdaság és a vidék jövőképe. Mosonmagyaróvár. Konferencia kiadvány I. kötet. 196-203.

Pap, J.-Pap, V.-Pap, N.-Tuller, P. (2009b): A termésbecslés értékelése. Mezőgazdaság és a vidék jövőképe. Mosonmagyaróvár. Konferencia kiadvány II. kötet. 255-264.

Pap, J.-Petróczki, F.-Pap, V.-Gergely, I. (2009c): A termésbecslés jelentősége. V. Növénytermesztési Tudományos Nap. Akadémiai Kiadó. 173-176

Pap, J.-Földesi-Pap, V. (2010): A technológiafejlesztés kiindulópontja az állapotminősítés és a termésbecslés. Agrofórum. 21. évfolyam, 6. 14-18.

Pap, J.-Pap, N.-Földesi-Pap, V. (2011): A szántóföldi kelés szerepe a borsótermesztésben. Erdei Ferenc VI. Tudományos Konferencia. Kecskemét. I. Kötet. 462-466.

Pap, N.-Pap, J.-Schmidt, R. (2018): Öszi búza termésbecslés. Fenntartható agrárium és környezet, az Óvári Akadémia 200 éve - múlt és jelen, jövő. Programfüzet XXXVII. Óvári Tudományos Napok. 2018. november 9-10. Az előadások összefoglalói.123.o.

Pap, J. (2007): A termésbecslés szerepe és jelentősége. IKR Magazin 2007 Nyár

Pásztor, K. (1981): Kukorica. In Kováts, A Növénytermesztési praktikum. Mezőgazdasági kiadó. Budapest. 
Sharma, R. C.-Smith, E. L.-McNew, R. W. (1991): Combining ability analysis for harvest index in winter wheat https://doi.org/10.1007/BF00021243

Simon, B. (1974): Termésbecslés módszerei Mezőgazdasági Kiadó Budapest.

Simon, B. (1985): Termésbecslés, - biztosítás, kárbecslés. In Menyhért (szerk.) A kukoricatermesztés kézikönyve. Mezőgazdasági Kiadó. Budapest.

Sváb, J. (1981): Biometriai módszerek a kutatásban. Mezőgazdasági Kiadó.

Trnka, M.-Dubrovský, M.-Semerádová, Žalud, Z.(2004) Projections of uncertainties in climate change scenarios into expected winter wheat yields https://doi.org/10.1007/s00704-004-0035-x 
